\title{
Microbiome Changes of Endemic Lake Baikal Sponges during Bleaching Syndrome Development
}

\author{
Valeria Itskovich ${ }^{1, * \mathbb{D}}$, Oxana Kaluzhnaya ${ }^{1}$, Olga Glyzina ${ }^{1}$, Ragothaman Prathiviraj ${ }^{2}$, George Seghal Kiran ${ }^{3}$ and \\ Joseph Selvin ${ }^{2}$ (1) \\ 1 Limnological Institute, Siberian Branch of the Russian Academy of Sciences, 3 Ulan-Batorskaya, \\ 664033 Irkutsk, Russia; x-sun77@rambler.ru (O.K.); glyzina@lin.irk.ru (O.G.) \\ 2 Department of Microbiology, School of Life Sciences, Pondicherry University, Puducherry 605014, India; \\ raj.prathivi@gmail.com (R.P.); josephselvinss@gmail.com (J.S.) \\ 3 Department of Food Science and Technology, School of Life Sciences, Pondicherry University, \\ Puducherry 605014, India; seghalkiran@gmail.com \\ * Correspondence: itskovich@mail.ru
}

check for updates

Citation: Itskovich, V.; Kaluzhnaya, O.; Glyzina, O.; Prathiviraj, R.; Seghal Kiran, G.; Selvin, J. Microbiome Changes of Endemic Lake Baikal Sponges during Bleaching Syndrome Development. Diversity 2021, 13, 653. https://doi.org/10.3390/d13120653

Academic Editor: Michael Wink

Received: 16 November 2021

Accepted: 2 December 2021

Published: 8 December 2021

Publisher's Note: MDPI stays neutral with regard to jurisdictional claims in published maps and institutional affiliations.

Copyright: (c) 2021 by the authors. Licensee MDPI, Basel, Switzerland. This article is an open access article distributed under the terms and conditions of the Creative Commons Attribution (CC BY) license (https:/ / creativecommons.org/licenses/by/ $4.0 /)$.

\begin{abstract}
The sponge (Porifera) microbiome is an indicator of both natural and anthropogenic stressors. Studying Baikal sponge microbial communities could help reveal if there is a connection between bacterial symbionts and a mass sponge bleaching event that was recently detected; 16S rRNA sequencing was performed among healthy and diseased freshwater sponges of Lubomirskia baikalensis and Baikalospongia intermedia, which were collected from Lake Baikal, Russia. A phylum-based taxonomic classification showed that Chlorophyta, Acidobacteria, Bacteroidetes, Actinobacteria and Cyanobacteria were most abundant across samples. When comparing healthy and diseased L. baikalensis samples, large variations in microbial composition were found the phylum level. Comparative analyses, which were performed for the first time for $B$. intermedia, showed a decrease in Chlorophyta (unicellular green algae) and an increase in Bacteroidetes and Cyanobacteria in diseased specimens. At the genus level, the Opitutus (Verrucomicrobia), Planctomyces, and Nitrospira content increased in all diseased sponges, which reflected a general tendency toward an increase in Cyanobacteria in diseased sponges. Comparative analysis of the diseased and healthy sponge metagenomes showed that diseased sponges underwent various nonspecific changes in bacterial composition. The bacterial community composition is probably influenced by sponge type and degree of disease affection.
\end{abstract}

Keywords: Porifera; microbiome; sponge disease; $16 \mathrm{~S}$ rRNA sequencing; Baikal

\section{Introduction}

Sponges (Porifera) constitute an important component of marine and freshwater ecosystems because of their species' richness, abundance, and key functional roles [1-4]. Sponges are inhabited by a wide variety of microorganisms, including archaea, heterotrophic bacteria, cyanobacteria, microscopic algae (green, red, cryptophytic, diatoms), dinoflagellates, and fungi; these microorganisms account for up to 50\% of their biomass [5-7]. Sponge bacterial communities tend to be dominated by Gamma-, Alphaproteo-bacteria, Actinobacteria, Cyanobacteria, Chloroflexi and Poribacteria [8-10].

Sponge symbiotic communities are based on complex functional relationships that were formed during the adaptation of the entire community to environmental conditions [11,12]. Microorganisms can be alternative sources of energy and carbon for the sponge, take part in the nitrogen cycle, protect against oxidative stress, and produce various bioactive metabolites $[9,12,13]$. In aquatic ecology, metagenomic approaches make it possible to investigate complex microbial communities and their interactions with the host and with the environment. 
Studies on the effects of increased temperature and ocean acidification on marine Porifera revealed that microbial symbiotic communities play an important role in maintaining sponge health and survival $[11,14]$. Under stress, sponge species undergo compositional and functional shifts in the microbiome [10,15-19]. Most research has been conducted on the microbial associations of marine sponges. Symbiotic associations of freshwater sponges have been insufficiently studied, even though these sponges also have diverse microbiomes including Actinobacteria, alpha-, beta-proteobacteria, Verrucomicrobia, and Flavobacterium [20-26].

Lake Baikal is the world's oldest and deepest lake, estimated to be 35 million years old with a maximum depth of $1647 \mathrm{~m}$. The Lake Baikal endemic sponge family Lubomirskiidae constitutes the bulk of the benthic biomass and includes 14 described species and two subspecies [27-29]. Sponges form the main part of the benthos biomass and, as sedentary biofiltrators, play an important role in the lake's ecology. Lubomirskia baikalensis Pallas, 1776 is a benthic littoral and sublittoral species that inhabits depths from 3-120 m. Lubomirskia baikalensis is a branched sponge that can grow to over $1 \mathrm{~m}$ and forms underwater forests at depths of 8-15 m. Baikalospongia intermedia Dybowsky,1880 is an overgrowing sponge that occurs at all depths, including the deep-water zone. B. intermedia and L. baikalensis are the most widespread species [29,30].

An ecological crisis has been observed in the littoral area of the lake since 2011 [31]. An important sign of the ecological crisis is the mass death of the sponges, and in some regions of Lake Baikal, $100 \%$ of the individuals are affected [31-34]. Studying Baikal sponge microbial communities could help reveal if there is a connection between bacterial symbionts and a mass sponge bleaching event that was recently detected.

Climate warming, coastal eutrophication, accumulation of toxic industrial contaminants, or infection with pathogens are indicated as possible reasons for the mass death of Baikal sponges [31-36]. The revealed narrow temperature optimum of L. baikalensis indicates the probable effect of increased temperature in the lake on disease development [33]. These findings correlate with the findings of numerous studies of sea sponges and corals, which also showed the influence of climate warming on the development of several diseases of these organisms [11,37-41]. However, metagenomic studies of the effect of disease on the composition of the symbiotic community of Baikal sponges are rare.

The diversity of $16 \mathrm{~S}$ rRNA genes in the microbial community of diseased L. baikalensis revealed the predominance of Cyanobacteria and low abundance of Bacteroidetes and Betaproteobacteria [32]. It was also found that the mucous films on the surface of diseased sponges were formed by cyanobacteria of the order Oscillatoriales, which included representatives of the genera Tychonema, Phormidium, and Leptolyngbya [42]. Other results of $16 \mathrm{~S}$ rRNA gene sequencing revealed that, in diseased sponges, the most represented OTUs belong to the families Oscillatoriaceae, Cytophagaceae, Flavobacteriaceae, Chitinophagaceae, Sphingobacteriaceae, Burkholderiaceae, Rhodobacteraceae, Comamonadaceae, Oxalobacteraceae and Xanthomonadaceae [35]. A comparison of healthy and diseased sponge microbiomes showed an increase in the number of Bacteroidetes and Proteobacteria, and the absence of a specific pathogen in diseased samples [36]. Bacteroidetes and Proteobacteria (families Flavobacteriaceae, Burkholderiaceae and Moraxellaceae) are abundant in diseased sponges [43]. It was confirmed that mat-forming cyanobacteria Tychonema plays a special role in the disease and death of Baikal sponges [44]. Moreover, studies of diseased sponge microbiomes were mostly carried out for L. baikalensis, even though other species are also susceptible to disease. Thus, the currently available data on the Baikal sponge microbial communities are limited and contradictory.

In this work, we carried out a comparative metagenomic analysis of the diseased and healthy sponges of two Lubomirskiidae species, L. baikalensis and B. intermedia, which were collected at two different time points. 


\section{Materials and Methods}

Samples of healthy and diseased L. baikalensis and B. intermedia were collected by SCUBA in Southern (Bolshie Koty 51 $53^{\prime} 54.4^{\prime \prime} \mathrm{N}, 105^{\circ} 04^{\prime} 15.3^{\prime \prime} \mathrm{E}$ and Chertov most $51^{\circ} 54^{\prime} 41.9^{\prime \prime} \mathrm{N}$, $105^{\circ} 13^{\prime} 29.2^{\prime \prime}$ E) and Northern (Severobykalsk $55^{\circ} 60^{\prime} 93.4^{\prime \prime}$ N, $109^{\circ} 34^{\prime} 80.3^{\prime \prime}$ E) basins of Lake Baikal in 2015 and 2006 at 10m depth. The description of the samplesare shown in Table 1. Sponge samples were frozen in liquid nitrogen for molecular analysis and were fixed in $70 \%$ ethanol for morphological examination. Spicule and skeleton preparation were performed as previously described [27] and were examined using an Olympus CX22 microscope. DNA extraction was performed using the RIBO-sorb RNA/DNAextraction kit (InterLabService, Moscow, Russia). DNA quality was assessed by running a subsample on a $1 \%$ agarose gel and the quantity of DNA was measured using a NanoVue (GE Healthcare).

Table 1. A detailed experimental determination of the effect of healthy and bleached freshwater sponges Lubomirskiabaikalensis and Baikalospongia intermedia collected from Baikal Lake, Russia.

\begin{tabular}{|c|c|c|c|c|c|c|c|c|}
\hline S. No. & BioProject ID & BioSample ID & $\begin{array}{l}\text { Sample } \\
\text { Name }\end{array}$ & Species & $\begin{array}{l}\text { Nature of } \\
\text { the Sample }\end{array}$ & $\begin{array}{l}\text { Base Pair } \\
\text { Count }\end{array}$ & Seq. Count & Location \\
\hline 1 & PRJNA665339 & SAMN16252099 & LBH1 & L. baikalensis & Healthy & $64,423,962$ & 254,909 & $\begin{array}{c}\text { Bolshie Koty, } \\
\text { Baikal, } \\
\text { Russia }\end{array}$ \\
\hline 2 & & SAMN16252100 & LBB1 & L. baikalensis & Bleached & $92,784,188$ & 367,304 & $\begin{array}{c}\text { Bolshie Koty, } \\
\text { Baikal, } \\
\text { Russia }\end{array}$ \\
\hline 3 & & SAMN16252101 & BIH1 & B. intermedia & Healthy & $72,441,375$ & 286,657 & $\begin{array}{c}\text { North Baikal, } \\
\text { Russia }\end{array}$ \\
\hline 4 & & SAMN16252102 & BIB1 & B. intermedia & Bleached & $53,745,195$ & 212,772 & $\begin{array}{c}\text { North Baikal, } \\
\text { Russia }\end{array}$ \\
\hline 5 & & SAMN16252103 & LBH2 & L. baikalensis & Healthy & $42,470,245$ & 168,170 & $\begin{array}{c}\text { Bolshie Koty, } \\
\text { Baikal, } \\
\text { Russia }\end{array}$ \\
\hline 6 & & SAMN16252104 & $\mathrm{LBH} 3$ & L. baikalensis & Healthy & $51,347,284$ & 203,100 & $\begin{array}{c}\text { Chertov } \\
\text { most, South } \\
\text { Baikal, } \\
\text { Russia }\end{array}$ \\
\hline 7 & & SAMN16252105 & LBB2 & L. baikalensis & Bleached & $63,233,204$ & 250,215 & $\begin{array}{c}\text { Chertov } \\
\text { most, South } \\
\text { Baikal, } \\
\text { Russia }\end{array}$ \\
\hline
\end{tabular}

The V3-V4 region of the 16S rRNA gene was amplified with primers 341F-806R [45] using Illumina MiSeq 250 bp chemistry. The PCR conditions were as follows: initial denaturation at $95^{\circ} \mathrm{C}$ for $2 \mathrm{~min}$; followed by 25 cycles: denaturation at $95 \mathrm{C}$ for $30 \mathrm{~s}$, anneal at $55 \mathrm{C}$ for $30 \mathrm{~s}$, extension at $72 \mathrm{C}$ for $30 \mathrm{~s}$; the final extension at $72 \mathrm{C}$ for $8 \mathrm{~min}$. The complete dataset of seven paired-end healthy (LBH1, LBH2, LBH3, BIH1) and bleached (LBB1, LBB2, BIB1) freshwater sponge samples were generated by a fastQ file format. The primary analysis of NGS sequencing data, the removal of short and chimeric sequences, clustering in OTUs (operational taxonomic units), an assessment of biodiversity by calculating ACE, Chao1, and Shannon indices were carried out using the Mothur v.1.22.0 program (http: / / www.mothur.org, accessed on 1 November 2021). The Pyrosequencing pipeline program (http:/ / pyro.cme.msu.edu, accessed on 1 November 2021) was used to determine species diversity and taxonomic composition and to compare communities. Data cluster analysis was performed using the Complete Linkage Clustering program, which is part of the Pyrosequencing pipeline.

The metagenomic analysis was performed using the MG-RASTserverV4.0.3 software package [46]. Sequence similarity search of the 16s rRNA gene was performed against the available biological database SILVA. The best hits were classified based on the percentage of identity and sequence query coverage. The rarefaction curve plot was used to annotate 
the species richness among the samples based on Rarefaction Curve Analysis [47-50]. A genus-level relative abundance of an operational taxonomic unit (OTUs) was computed and compared for a better understanding of the composition of a microbial community among the selected samples.

The relative abundance of OTUs at genus level comparison was performed using the Morpheus online tool (https:/ / software.broadinstitute.org/morpheus/, accessed on 1 November 2021). We carried out the clustering heat map with a complete linkage method using the Euclidian distance metric [51], and One minus Pearson correlation metric [52] implemented in the Morpheus tool. The genus identified in OTUs from seven selected samples was further compared with five-set and two-set interactive Venn diagrams using the InteractiVenn tool (http:/ / www.interactivenn.net/, accessed on 1 November 2021).

\section{Results}

\subsection{Analysis of Essential Parameters and Taxonomic Hit Distribution}

Out of seven analyzed samples, five belong to L. baikalensis (three healthy and two bleached samples) and B. intermedia (one healthy and one bleached sample). Sequences were deposited in the NCBI-SRA portal (PRJNA665339). The basic nucleotide features (Base pair and total sequence count) of the selected samples are shown in Table 1.

We performed a taxonomic hits distribution of taxa using a contigLCA algorithm finding a single consensus taxonomic entity for all features on each individual sequence. The bacterial community was dominated by Chlorophyta, Acidobacteria, Bacteroidetes, Actinobacteria and Cyanobacteria as shown in Figure 1a. It shows that the overall 21 phyla play a major role in the growth physiology and maintenance of their cell survivability in freshwater environments. Samples LBH3 and BIH1 have a high relative abundance of Chlorophyta (80\%) while this is $50 \%$ or less in other samples. Acidobacteria, Proteobacteria, Bacteroidetes, Cyanobacteria and Actinobacteria are found to be abundant and distributed nonspecifically between healthy and bleached samples (Figure 1b).

(a)

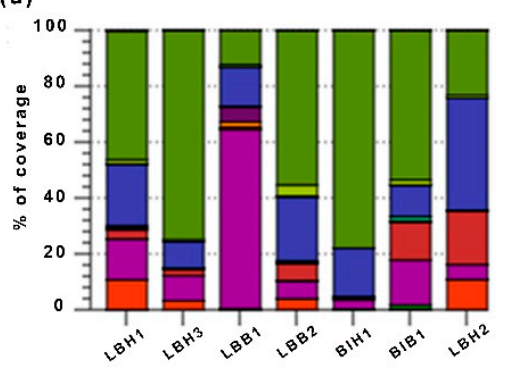

Acidobacteria

Actinobacteria

Aquificae

Bacillariophyta

Bacteroidetes

Chlamydiae

Chloroflexi

Chlorophyta

Cyanobacteria

Deinococcus

Dictyoglomi

Euglenida

Euryarchaeota

Fibrobacteres

Firmicutes

Fusobacteria

Nitrospirae

Phaeophyceae

Planctomycetes

Proteobacteria

Spirochaetes (b)
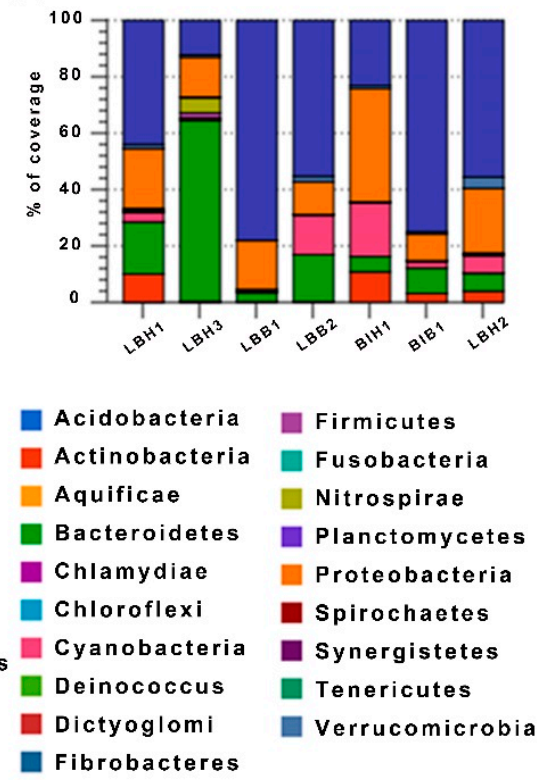

Figure 1. A phylum based bar diagram represents overall reads (a) and separated bacterial reads (b) classification was predicted among healthy and bleached freshwater sponges Lubomirskia baikalensis and Baikalospongia intermedia.

\subsection{Analysis of Rarefaction Curve}

The rarefaction curve plot was used to annotate the species richness among the samples. From our analysis, we identified that the species count is increased in bleached 
samples of L. baikalensis (LBB1) upon 360,000 sequence reads. Whereas LBH3 has increased its species count to 1000 within a short number of sequence reads $(250,000)$. It clearly indicates that a larger amount of bacterial diversity was found in the LBH3 sample. Whereas other samples have 600-800 species count within a short read. The samples LBH2 are found to be a low species diversity sample (Figure 2). Bacterial diversity increases in bleached samples of $B$. intermedia.

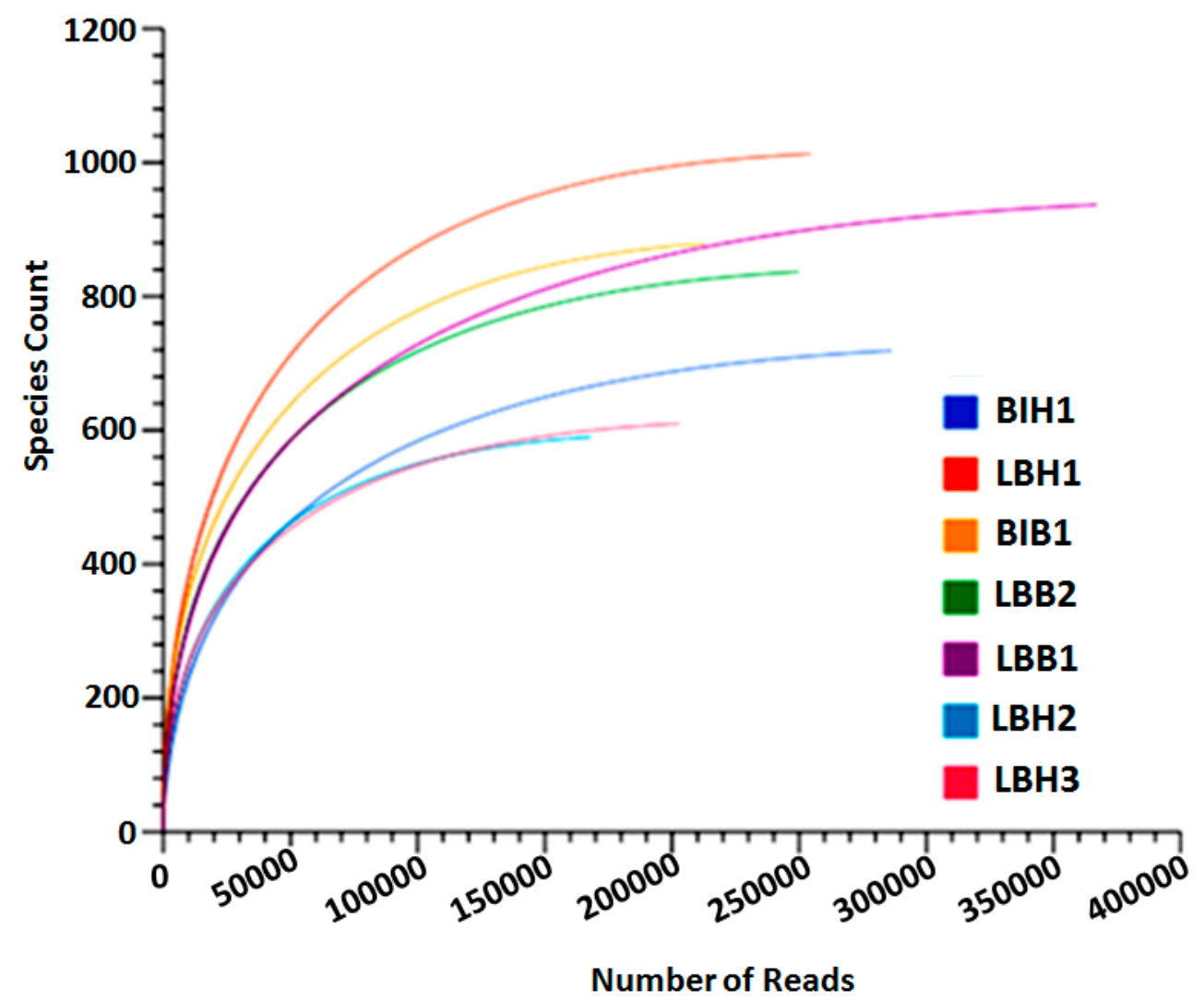

Figure 2. A phylum based rare-fraction curve was predicted among healthy and bleached fresh-water sponges Lubomirskia baikalensis and Baikalospongia intermedia.

\subsection{Analysis of Relative Abundances of OTUs at Genus Level}

The genus based rank abundance and operational taxonomic units were computed for top hits from the selected samples. It shows that a predominance of bacterial genera, such as Flavobacterium, Eubacterium, Candidadus and Tetrasphaera, are found to be abundant in a healthy sample of L. Baikalensis (LBH1), while Synechococcus was highly abundant in $L$. baikalensis (LBH2). While compared to the bleached samples, few genera, such as Nitrospira, Planctomyces, Prolixibacter and Clostridium, are found to be abundant (Figure 3a). We further compared the top 50 relative abundance genera; it shows that the overall 16 genera are commonly found in both healthy and bleached L. baikalensis samples (Figure 3b). Whereas 30 common and 20 unique genera are found in two healthy L. baikalensis samples (LBH1 and LBH2) (Figure 3c). 

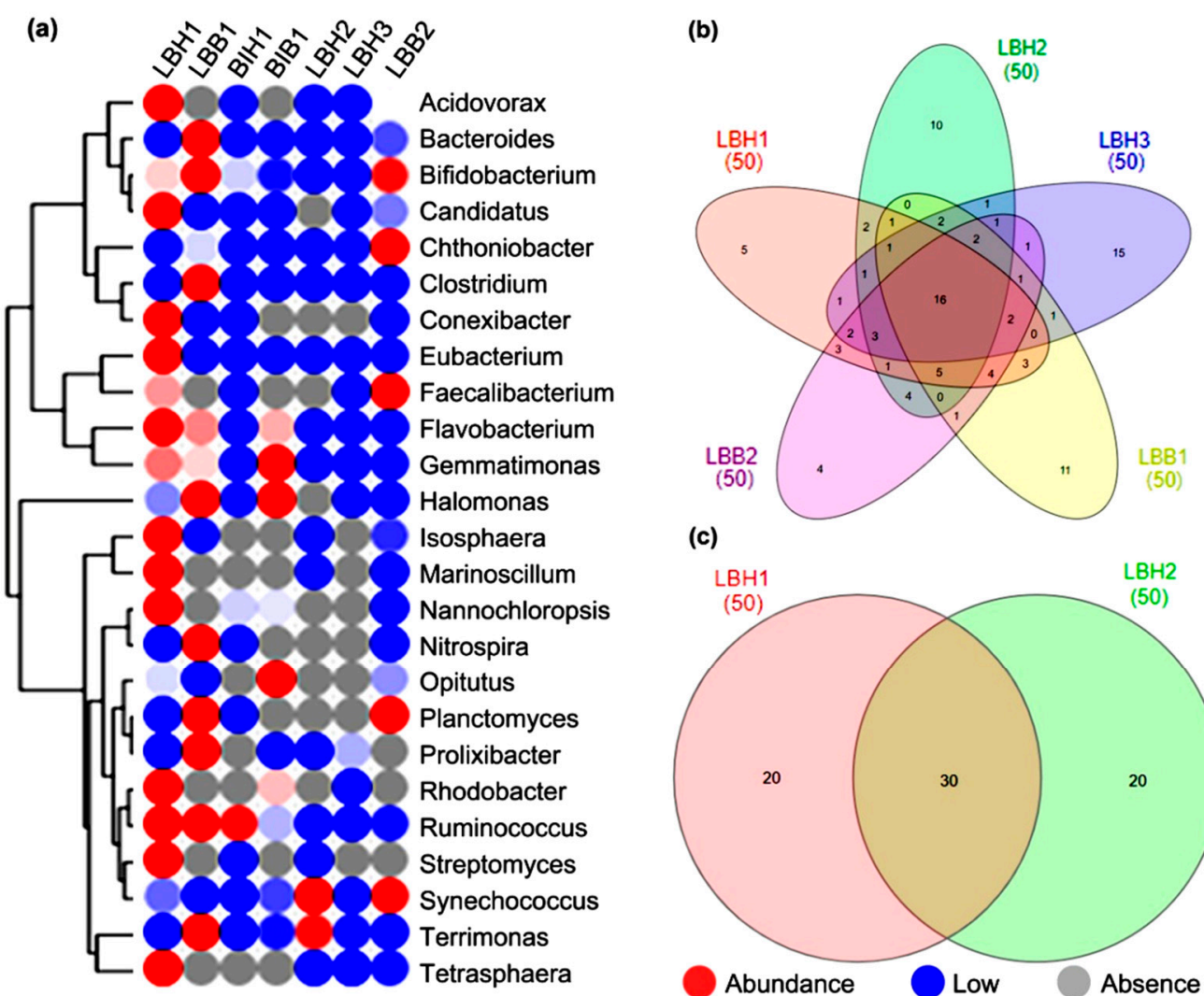

(c)

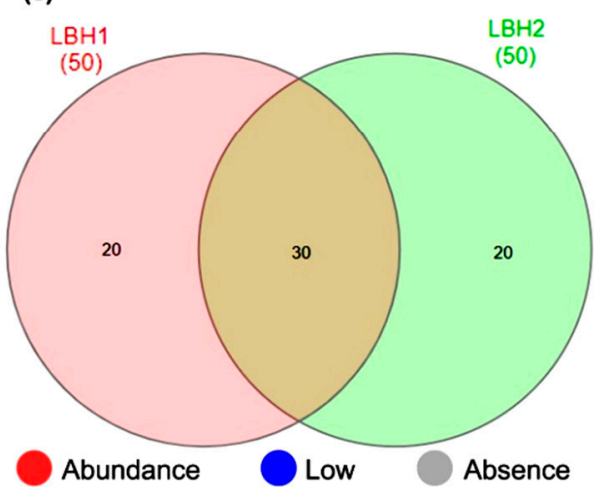

Figure 3. Top hits rank abundance plot comparison based on genus-level for selected healthy and bleached sponges. (a) The heat map represents the abundances of annotations of taxonomic richness and evenness on a log scale. $(\mathbf{b}, \mathbf{c})$ The Venn diagram represents the common and unique genus found in the samples.

\subsection{Analysis of OTUs within Genus Level}

We further classified and compared the top best enriched operational taxonomic units found between the samples. The heat map represents the distribution of taxa using a contig LCA algorithm, finding a single consensus taxonomic entity for all features on each individual sequence. This shows that the genera Candidatus, Eubacterium, Flavobacterium, Nitrospira, Plactomyces, Prolixibacter, Terrimonas, Bifidobacterium are abundant in healthy and bleached L. baikalensis samples. Whereas in B. intermedia (bleached) samples, the genera Coptotermes, Gemmatimonas, Halomonas, Opitutus are found to be abundant (Figure 4a). More than 15 genera from healthy and nine genera from bleached samples are uniquely found in L. baikalensis (Figure 4b) whereas in B. intermedia, 23 common and 27 unique genera are found in both healthy and bleached samples (Figure 4c). 
(a)

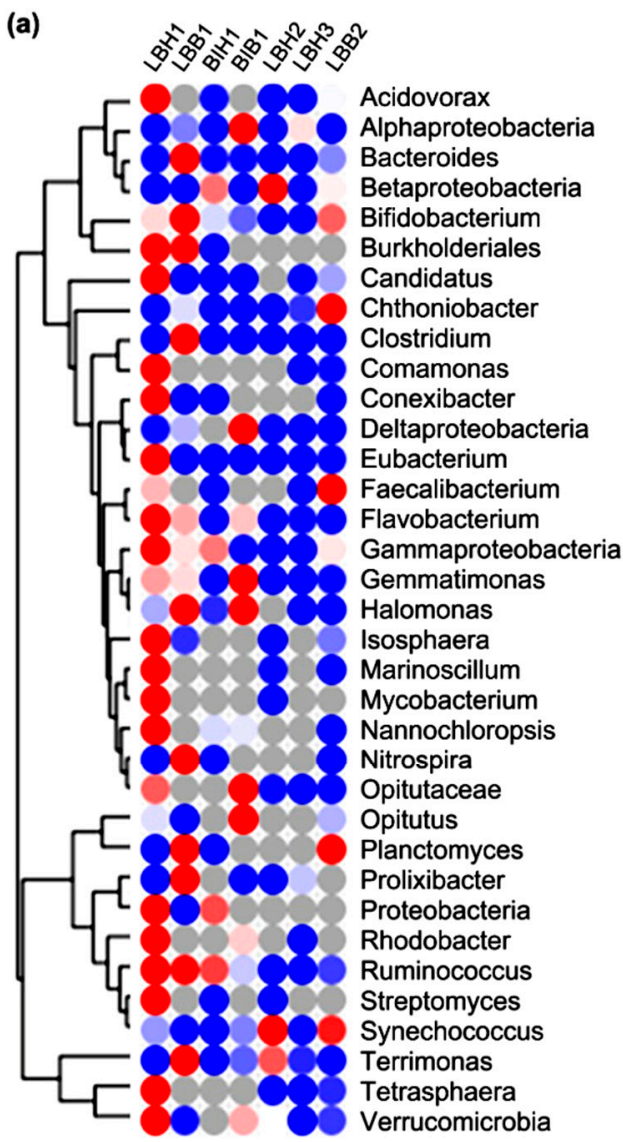

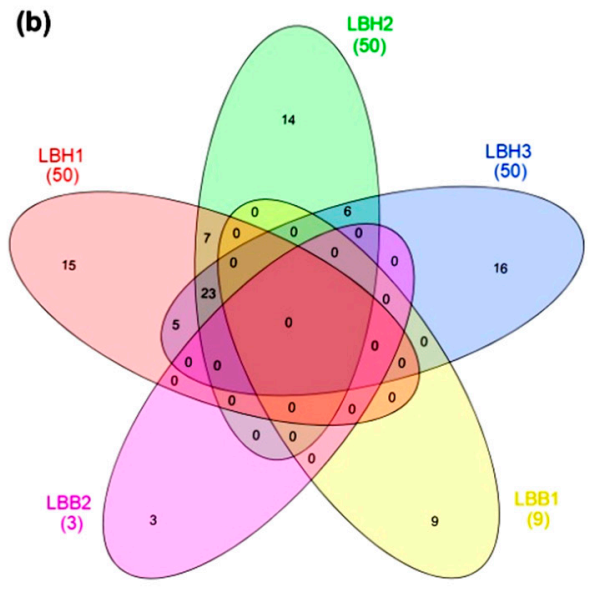

(c)

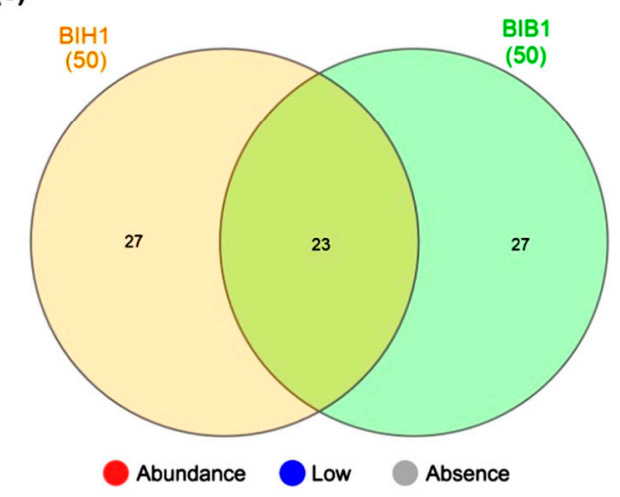

Figure 4. Top hits operational taxonomic units comparison based on genus-level for selected healthy and bleached sponges. (a) The heat map represents the abundances of annotations of taxonomic richness and evenness on a $\log$ scale. $(\mathbf{b}, \mathbf{c})$ The Venn diagram represents the common and unique genus found in the samples.

\section{Discussion}

A phylum-based taxonomic classification showed that the microbiome genera that were most abundant across all samples belonged to Acidobacteria, Bacteroidetes, Actinobacteria and Cyanobacteria. Chlorophyta is also abundant in microbiomes. Moreover, the composition of the microbiome is nonspecifically altered in diseased L. baikalensis. These phyla were found in moderate abundance in the samples of both healthy and diseased individuals. Our samples of healthy and diseased L. baikalensis were collected at two different collection points and at different times (2006 and 2015). Therefore, fluctuations in the microbial community composition among healthy sponges can be caused by different environmental conditions in Lake Baikal during a given time period. In marine sponges, the microbial composition has substantial intraspecific and interspecific variability, and varies by depth and season [15]. Thus, when comparing healthy and diseased L. baikalensis samples, we did not reveal specific changes in diseased sponge bacterial composition. We have shown that, among healthy L. baikalensis, there are significant differences in the content of Chlorophyta, Bacteroidetes, Cyanobacteria and other phyla. These results are consistent with some previously obtained results. When studying the 16SrRNA gene diversity of L. baikalensis microbial communities in discolored tissue areas, Cyanobacteria were dominant and there was a low abundance of Bacteroidetes and Betaproteobacteria compared to healthy samples [32]. Other 16S rRNA gene sequencing results revealed that, in diseased sponges, Cyanobacteria, Bacteroidetes, Alphaproteobacteria, Betaproteobacteria, and Gammaproteobacteria showed more than five-fold increases in abundance compared to healthy sponges [35]. Simultaneously, a comparison of the microbiomes of healthy and diseased sponges collected in 2011 and 2015 showed an increase in the number of Bac- 
teroidetes and Proteobacteria [36]. There was no clear difference between the microbiomes of diseased and healthy sponges; for example, a high content of Verrucomicrobia (class Methylacidiphilae) was characteristic of both diseased and healthy sponges [36].

Cyanobacteria probably play an important role in the development of the disease of the Baikal sponges [42,44]. Proliferation of benthic cyanobacteria on Lake Baikal can be observed during all seasons $[31,44]$. The influence of the season on the microbiome and diseases of the Baikal sponges has not been studied previously. Although other studies analyzed samples collected in different seasons, there was no comparative analysis between them. With our limited number of samples, we demonstrate a difference in the microbiome of healthy L. baikalensis collected in different seasons, but more samples need to be analyzed.

Most previous studies of diseased sponge microbiomes were only carried out for L. baikalensis, even though other species are also susceptible to disease. For the first time, we performed a comparative analysis of diseased and healthy B. intermedia; we identified a decrease in Chlorophyta and an increase in Bacteroidetes and Cyanobacteria in diseased specimen. Until now, very few studies have been conducted on the microbiome in B. intermedia [21,24,26]. Proteobacteria, Actinobacteria, Planctomycetes, Cloroflexi, Verrucomicrobia, Acidobacteria, Chlorobi and Nitrospirae were identified within the $B$. intermedia microbiome [21]. It was noted that deep-sea habitat conditions affected the taxonomic diversity of microbiome bacteria and the presence of functionally significant microorganisms in communities. In microbial associations of Baikalospongia sp., the bacterial phyla Bacteroidetes, Proteobacteria, and Actinobacteria were predominantly identified [24]. Seo et al. [26] found differences in the bacterial species composition and diversity among $B$. intermedia, L. baikalensis, and S. papyracea. The bacterial communities in B. intermedia and L. baikalensis were highly similar because both species were collected from shallow zones, and Cyanobacteria and Proteobacteria accounted for the highest proportion [26]. Our data showed that Chlorophyta, Acidobacteria, Bacteroidetes, Proteobacteria and Cyanobacteria were predominant in healthy $B$. intermedia. Thus, different Baikal sponge species and different samples of the same species have differences in microbial composition; however, at present, we cannot say whether they are host- or habitat-specific.

At the genus level, the Opitutus (Verrucomicrobia) content increased or appeared in all diseased sponges. Verrucomicrobia, which are predominantly heterotrophic microorganisms that decompose hydrocarbon substrates, are widespread in marine, freshwater, soil, and hot spring ecosystems. Verrucomicrobia are characteristic of Baikal sponge communities [32]. It has been shown that Verrucomicrobia abundance is positively correlated with an increased nutrient content, phosphate availability, and seasonal algal blooms, and can change depending on the season $[24,32,42]$. The number of Planctomyces also increased in diseased L. baikalensis samples. Planctomycetes in freshwater ecosystems are generally considered minor phyla. Representatives of this phylum participate in the an-aerobic oxidation of ammonium and have the ability to degrade hydrocarbons produced by phytoplankton [53]. The genus Nitrospira also appeared or increased in abundance in diseased $L$. baikalensis, which reflected a general trend toward an increase in cyanobacteria in diseased sponges. Additionally, in diseased sponges, tendencies toward a decrease in the number or disappearance of some proteobacteria and planctomycetes were noted. Streptomyces and Acidovorax disappeared from diseased sponges. The number of Isosphaera, which are acidophilic planktomycetes capable of degrading numerous heteropolysaccharides, decreased in two diseased L. baikalensis samples.

In marine sponges, elevated temperature can disrupt the functionally important microbial symbionts [39,54,55]. Microbial community changes upon exposure to elevated temperature can manifest as a loss of specific bacterial and archaeal taxa, and increases in opportunistic microorganisms $[11,39,55]$. Global warming has led to several sponge mortality events [37,40,41,56,57]; in Lake Baikal, a probable cause of sponge disease is also increased water temperature. The occurrence of diseased sponges throughout Lake Baikal, including in ecologically less disturbed areas [34], also supports this idea. Previously, a decrease in the heat shock protein (HSP70) content of diseased sponges with various types 
of lesions was shown, which indicates a suppression of their physiological and energetic states [33]. This suppression may occur even before the development of visible signs such as lesions, which are the result of the weakening of the spongy immunity. For example, in corals, the microbiome can shift prior to bleaching [58,59]. The composition of the sponge bacterial community is probably also influenced by the degree of disease involvement. Because the extent of disease involvement is difficult to visually determine when collecting sponges, samples identified as healthy may already be at the stage of early destruction of the microbiome. This may explain the lack of a clear picture of microbial composition changes in diseased sponges. In addition, it is possible that studies of changes in the eukaryotic community composition will also elucidate the reasons for the destruction of diseased sponge microbiomes.

\section{Conclusions}

These results help to clarify the nature of changes in symbiotic relationships during discoloration syndrome development in freshwater sponges. We showed large fluctuations in microbial composition in diseased and healthy sponges based on our previously published data, which may be due to different collection points, depths and collection seasons. Given the limited number of samples, we analyzed experiments under the same conditions that are needed to identify the change in microbiome composition between healthy and diseased individuals and its causes. We also showed interspecific differences in discoloration syndrome development in Baikal sponges. Thus, more data are also needed from samples at different depths and seasons, and from different Lubomirskiidae species.

Author Contributions: Conceptualization, V.I. and J.S.; methodology, V.I., O.G. and O.K.; software, R.P., G.S.K. and J.S.; validation, V.I. and J.S.; formal analysis, R.P. and G.S.K.; investigation, V.I. and O.G.; data curation, V.I., R.P. and G.S.K.; writing—original draft preparation, V.I., O.K., R.P., G.S.K. and J.S.; writing-review and editing, V.I., O.K., R.P., G.S.K. and J.S.; visualization, R.P., G.S.K. and J.S.; supervision, V.I. and J.S.; project administration, V.I. and J.S.; funding acquisition, V.I. and J.S. All authors have read and agreed to the published version of the manuscript.

Funding: The reported study was funded by RFBR and DST according to the research project № 19-54-45034, by RFBR according to the research project № 20-04-00868 and basic funding, project number 0279-2021-0011.

Institutional Review Board Statement: Not applicable.

Informed Consent Statement: Not applicable.

Data Availability Statement: The raw sequencing reads were deposited in the NCBI-SRA portal (PRJNA665339).

Acknowledgments: We thank Igor Khanaev and Alexandr Kupchinsky for the help with samples collection. We thank Mallory Eckstut, from Edanz (https://www.edanz.com/ac, accessed on 1 November 2021) for editing a draft of this manuscript. We thank the three anonymous reviewers for their valuable comments. This study was carried out in the Large-Scale Research Facilities “Experimental Freshwater Aquarium Complex for Baikal Hydrobionts" (http:/ / www.lin.irk.ru/aqua, accessed on 1 November 2021).

Conflicts of Interest: The authors declare no conflict of interest.

\section{References}

1. Diaz, M.C.; Rützler, K. Sponges: An essential component of Caribbean coral reefs. Bull. Mar. Sci. 2001, 69, 535-546.

2. Bell, J.J.; Biggerstaff, A.; Bates, T.; Bennett, H.; Marlow, J.; McGrath, E.; Shaffer, M. Sponge monitoring: Moving beyond diversityand abundance measures. Ecol. Indic. 2017, 78, 470-488. [CrossRef]

3. Bell, J.J. The functional roles of marine sponges. Estuar. Coast. Shelf Sci. 2008, 79, 341-352. [CrossRef]

4. Van Soest, R.W.M.; Nicole Boury-Esnault, J.V.; Dohrmann, M.; Erpenbeck, D.; De Voogd, N.J.; Santodomingo, N.; Vanhoorne, B.; Kelly, M.; Hooper, J.N.; Hooper, A. Global diversity of sponges (Porifera). PLoS ONE 2012, 7, e35105. [CrossRef]

5. Hentschel, U.; Usher, K.M.; Taylor, M.W. Marine sponges as microbial fermenters. FEMS Microbiol. Ecol. 2006, 55, 167-177. [CrossRef] [PubMed] 
6. Webster, N.S.; Blackall, L.L. What do we really know about sponge-microbial symbioses. ISME J. 2009, 3, 1-3. [CrossRef] [PubMed]

7. Cervino, J.M.; Winiarski-Cervino, K.; Poison, S.W.; Goreau, T.; Smith, G.W. Identification of bacteria associated with a disease affecting the marine sponge Ianthella basta in New Britain, Papua New Guinea. Mar. Ecol. Prog. Ser. 2006, 324, 139-150. [CrossRef]

8. Choudhury, J.D.; Pramanik, A.; Webster, N.; Llewellyn, L.E.; Gachhui, R.; Mukherjee, J. Assessing the complex sponge microbiota: Core, variable and species-specific bacterial communities in marine sponges. ISME J. 2012, 6, 564-576. [CrossRef]

9. Hentschel, U.; Piel, J.; Degnan, S.M.; Taylor, M.W. Genomic insights into the marine sponge microbiome. Nat. Rev. Microbiol. 2012, 10, 641-654. [CrossRef]

10. Webster, N.S.; Thomas, T. The sponge hologenome. MBio 2016, 7, e00135-16. [CrossRef] [PubMed]

11. Fan, L.; Liu, M.; Simister, R.; Webster, N.S.; Thomas, T. Marine microbial symbiosis heats up: The phylogenetic and functional response of a sponge holobiont to thermal stress. ISME J. 2013, 7, 991-1002. [CrossRef]

12. Webster, N.S.; Luter, H.M.; Soo, R.M.; Botte, E.S.; Simister, R.L.; Abdo, D.; Whalan, S. Same, same but different: Symbiotic bacterial associations in GBR sponges. Front. Microbiol. 2012, 3, 444. [CrossRef] [PubMed]

13. Erwin, P.M.; Pita, L.; Lopez-Legentil, S.; Turon, X. Stability of sponge-associated bacteria over large seasonal shifts in temperature and irradiance. Appl. Environ. Microbiol. 2012, 78, 7358-7368. [CrossRef]

14. Morrow, K.M.; Fiore, C.L.; Lesser, M.P. Environmental drivers of microbial community shifts in the giant barrel sponge, Xestospongia muta, over a shallow to mesophotic depth gradient. Environ. Microbiol. 2016, 18, 2025-2038. [CrossRef]

15. Selvin, J.; Priya, S.; Seghal Kiran, G.; Thangavelu, T.; Sapna Bai, N. Sponge associated marine bacteria as indicators of heavy metal pollution. Microbiol. Res. 2009, 164, 352-363. [CrossRef] [PubMed]

16. Bourne, D.G.; Dennis, P.G.; Uthicke, S.; Soo, R.M.; Tyson, G.W.; Webster, N. Coral reef invertebrate microbiomes correlate with the presence of photosymbionts. NPG 2013, 7, 1452-1458. [CrossRef]

17. Bourne, D.G.; Morrow, K.M.; Webster, N.S. Insights into the coral microbiome: Underpinning the health and resilience of reef ecosystems. Annu. Rev. Microbiol. 2016, 70, 317-340. [CrossRef] [PubMed]

18. Botté, E.S.; Nielsen, S.; Abdul Wahab, M.A.; Webster, J.; Robbins, S.; Thomas, T.; Webster, N.S. Changes in the metabolic potential of the sponge microbiome under ocean acidification. Nat. Commun. 2019, 10, 4134. [CrossRef]

19. Kiran, G.S.; Sekar, S.; Ramasamy, P.; Thinesh, T.; Hassan, S.; Lipton, A.N.; Ninawe, A.S.; Selvin, J. Marine sponge microbial association: Towards disclosing unique symbiotic interactions. Mar. Environ. Res. 2018, 140, 169-179. [CrossRef] [PubMed]

20. Kaluzhnaya, O.V.; Krivich, A.A.; Itskovich, V.B. Diversity of 16S rRNA Genes in Metagenomic Community of the Freshwater Sponge Lubomirskia baicalensis. Russ. J. Genet. 2012, 48, 851-854. [CrossRef]

21. Kaluzhnaya, O.V.; Itskovich, V.B. Phylogenetic Diversity of Microorganisms Associated with the Deep-Water Sponge Baikalospongia intermedia. Russ. J. Genet. 2014, 50, 667-676. [CrossRef]

22. Kaluzhnaya, O.V.; Itskovich, V.B. Distinctive features of the microbial diversity and the polyketide synthase genes spectrum in the community of the endemic Baikal sponge Swartschewskia papyracea. Russ. J. Genet. 2016, 52, 38-48. [CrossRef]

23. Costa, R.; Keller-Costa, T.; Gomes, N.C.; da Rocha, U.N.; van Overbeek, L.; van Elsas, J.D. Evidence for selective bacterial Communitystructuring in the freshwater sponge Ephydatia fluviatilis. Microb. Ecol. 2013, 65, 232-244. [CrossRef]

24. Gladkikh, A.S.; Kaluyzhnaya, O.V.; Belykh, O.I.; Ahn, T.S.; Parfenova, V.V. Analysis of bacterial communities of two Lake Baikal endemic sponge species. Mikrobiologiia 2014, 83, 682-693. [CrossRef] [PubMed]

25. Gaikwad, S.; Shouche, Y.S.; Gade, W.N. Microbial community structure of two freshwater sponges using Illumina MiSeq sequencing revealed high microbial diversity. AMB Expr. 2016, 6, 40. [CrossRef] [PubMed]

26. Seo, E.Y.; Jung, D.; Belykh, O.I.; Bukshuk, N.A.; Parfenova, V.V.; Joung, Y.; Kim, I.C.; Yim, J.H.; Ahn, T.-S. Comparison of bacterial diversity and species composition in three endemic Baikalian sponges. Ann. Limnol. 2016, 52, 27-32. [CrossRef]

27. Efremova, S.M. New genus and new species of sponges from family Lubomirskiidae Rezvoj, 1936. In Index of Animal Species Inhabiting Lake Baikal and Its Catchment Area; Timoshkin, O.A., Ed.; Nauka: Lake Baikal, Russia, 2004; Volume 1, pp. 1261-1278.

28. Bukshuk, N.A.; Maikova, O.O. A new species of Baikal endemic sponges (Porifera, Demospongiae, Spongillida, Lubomirskiidae). ZooKeys 2020, 906, 113-130. [CrossRef] [PubMed]

29. Itskovich, V.; Kaluzhnaya, O.; Veynberg, Y.; Erpenbeck, D. Endemic Lake Baikal sponges from deep water. 2: Taxonomy and bathymetric distribution. Zootaxa 2017, 4236, 335-342. [CrossRef]

30. Masuda, Y. Studies on the taxonomy and distribution of freshwater sponges in Lake Baikal. In Biosilica in Evolution, Morphogenesis and Nanobiotechnology; Müller, W.E.G., Grachev, M.A., Eds.; Springer: Berlin/Heidelberg, Germany, 2009; pp. 81-110. [CrossRef]

31. Timoshkin, O.A.; Samsonov, D.P.; Yamamuro, M.; Moore, M.V.; Belykh, O.I.; Malnik, V.V.; Sakirko, M.V.; Shirokaya, A.A.; Bondarenko, N.A.; Domysheva, V.M.; et al. Rapid ecological change in the coastal zone of Lake Baikal (East Siberia): Is the site of the world's greatest freshwater biodiversity in danger? J. Great Lakes Res. 2016, 42, 487-497. [CrossRef]

32. Kaluzhnaya, O.V.; Itskovich, V.B. Influence of Baikal sponge bleaching to taxonomic composition of symbiotic microorganisms. Russ. J. Genet. 2015, 51, 1335-1340.

33. Itskovich, V.B.; Shigarova, A.M.; Glyzina, O.Y.; Kaluzhnaya, O.V.; Borovskii, G.B. Heat shock protein 70 (Hsp70) response to elevated temperatures in the endemic Baikal sponge Lubomirskia baicalensis. Ecol. Indic. 2018, 88, 1-7. [CrossRef] 
34. Khanaev, I.V.; Kravtsova, L.S.; Maikova, O.; Bukshuk, N.; Sakirko, M.V.; Kulakova, N.V.; Butina, T.V.; Nebesnykh, I.A.; Belikov, S.I. Current state of the sponge fauna (Porifera: Lubomirskiidae) of Lake Baikal: Sponge disease and the problem of conservation of diversity. J. Great Lakes Res. 2018, 44, 77-85. [CrossRef]

35. Kulakova, N.V.; Sakirko, M.V.; Adelshin, R.V.; Khanaev, I.V.; Nebesnykh, I.A.; Perez, T. Brown Rot Syndrome and Changes in the Bacterial community of the Baikal Sponge Lubomirskia baicalensis. Microb. Ecol. 2018, 75, 1024-1034. [CrossRef] [PubMed]

36. Belikov, S.; Belkova, N.; Butina, T.; Chernogor, L.; Martynova-Van Kley, A.; Nalian, A.; Rorex, C.; Khanaev, I.I.; Maikova, O.; Feranchuk, S. Diversity and shifts of the bacterial community associated with Baikal sponge mass mortalities. PLoS ONE 2019, 14, e0213926. [CrossRef]

37. Cebrian, E.; Uriz, M.J.; Garrabou, E.; Ballesteros, E. Sponge mass mortalities in a warming Mediterranean. Are cyanobacteria harboring species worse off? PLoS ONE 2011, 6, e20211. [CrossRef] [PubMed]

38. Sokolow, S. Effects of a changing climate on the dynamics of coral infectious disease: A review of the evidence. Dis. Aquat. Org. 2009, 87, 5-18. [CrossRef]

39. Ramsby, B.D.; Hoogenboom, M.O.; Whalan, S.; Webster, N.S. Elevated seawater temperature disrupts the microbiome of an ecologically important bioeroding sponge. Mol. Ecol. 2018, 27, 2124-2137. [CrossRef] [PubMed]

40. Vicente, V.P. Regional commercial sponge extinction in the West Indies: Are recent climatic changes responsible? Mar. Ecol. Prog. Ser. 1989, 10, 179-191. [CrossRef]

41. Cerrano, C.; Bavestrello, G.; Bianchi, C.N.; Cattaneovietti, R.; Bava, S.; Morganti, C.; Morri, C.; Picco, P.; Sara, G.; Schiaparelli, S.; et al. A catastrophic mass-mortality episode of gorgonians and other organisms in the Ligurian Sea (North-Western Mediterranean), summer 1999. Ecol. Lett. 2000, 3, 284-293. [CrossRef]

42. Kaluzhnaya, O.; Itskovich, V. Molecular identification of filamentous cyanobacteria overgrowing the endemic sponge Lubomirskia baicalensis. Inland Waters 2017, 7, 267-271. [CrossRef]

43. Chernogor, L.; Klimenko, E.; Khanaev, I.; Belikov, S. Microbiome analysis of healthy and diseased sponges Lubomirskia Baicalensis by using cell cultures of primmorphs. PeerJ 2019, 7, e27851v1. [CrossRef] [PubMed]

44. Sorokovikova, E.; Belykh, O.; Krasnopeev, A.; Potapov, S.; Tikhonova, I.; Khanaev, I.; Kabilov, M.; Baturina, O.; Podlesnaya, G.; Timoshkin, O. First data on cyanobacterial biodiversity in benthic biofilms during mass mortality of endemic sponges in Lake Baikal. J. Great Lakes Res. 2020, 46, 75-84. [CrossRef]

45. Takahashi, S.; Tomita, J.; Nishioka, K.; Hisada, T.; Nishijima, M. Development of a prokaryotic universal primer for simultaneous analysis of Bacteria and Archaea using next-generation sequencing. PLoS ONE 2014, 9, e105592. [CrossRef]

46. Meyer, F.; Paarmann, D.; D'Souza, M.; Olson, R.; Glass, E.M.; Kubal, M.; Paczian, T.; Rodriguez, A.; Stevens, R.; Wilke, A.; et al. The metagenomics RAST server-A public resource for the automatic phylogenetic and functional analysis of metagenomes. BMC Bioinform. 2008, 9, 386. [CrossRef]

47. Hughes, J.B.; Hellmann, J.J.; Ricketts, T.H.; Bohannan, B.J.M. Counting the uncountable: Statistical approaches to estimating microbial diversity. Appl. Environ. Microbiol. 2001, 67, 4399-4406. [CrossRef] [PubMed]

48. Schloss, P.D.; Handelsman, J. Introducing DOTUR, a computer program for defining operational taxonomic units and estimating species richness. Appl. Environ. Microbiol. 2005, 71, 1501-1506. [CrossRef] [PubMed]

49. Prathiviraj, R.; Rajeev, R.; Fernandes, H.; Rathna, K.; Lipton, A.N.; Selvin, J.; Kiran, G.S. A gelatinized lipopeptide diet effectively modulates immune response, disease resistance and gut microbiome in Penaeus vannamei challenged with Vibrio parahaemolyticus. Fish. Shellfish Immunol. 2021, 112, 92-107. [CrossRef]

50. Schloss, P.D.; Handelsman, J. Toward a census of bacteria in soil. PLoS Comput. Biol. 2006, 2, e92. [CrossRef] [PubMed]

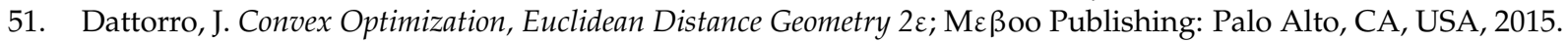

52. Wagner, J.G.; Aghajanian, G.K.; Bing, O.H. Correlation of performance test scores with tissue concentration of lysergic aciddiethylamide in human subjects. CPT 1968, 9, 635-638.

53. Woebken, D.; Teeling, H.; Wecker, P.; Dumitriu, A.; Kostadinov, I.; Delong, E.F.; Amann, R.; Glцckner, F.O. Fosmids of novel marine Planctomycetes from the Namibian and Oregon coast upwelling systems and their cross_comparison with planctomycete genomes. ISME J. 2007, 1, 419-435. [CrossRef]

54. Lemoine, N.; Buell, N.; Hill, A.L.; Hill, M.S. Assessing the utility of sponge microbial symbiont communities as models to study global climate change: A case study with Halichondria bowerbanki. In Porifera Research Biodiveristy, Innovation and Sustainability; Custodio, M.R., Lobo-Hajdu, G., Hajdu, E., Muricy, G., Eds.; Museu Nacional: Rio De Janeiro, Brazil, 2007 ; pp. $419-425$.

55. Webster, N.S.; Soo, R.; Cobb, R.; Negri, A.P. Elevated seawater temperature causes a microbial shift on crustose coralline algae with implications for the recruitment of coral larvae. ISME J. 2011, 5, 759-770. [CrossRef]

56. Sweet, M.J.; Bulling, M.T. On the importance of the microbiome and pathobiome in coral health and disease. Front. Mar. Sci. 2017, 4, 9. [CrossRef]

57. Lopez-Legentil, S.; Song, B.; McMurray, S.E.; Pawlik, J.R. Bleaching and stress in coral reef ecosystems: Hsp70 expression by the giant barrel sponge Xestospongia muta. Mol. Ecol. 2008, 17, 1840-1849. [CrossRef] [PubMed]

58. Bourne, D.; Iida, Y.; Uthicke, S.; Smith-Keune, C. Changes in coral-associated microbial communities during a bleaching event. ISME J. 2008, 2, 350-363. [CrossRef]

59. Lee, S.T.; Davy, S.K.; Tang, S.L.; Fan, T.-Y.; Kench, P.S. Successive shifts in the microbial community of the surface mucus layer and tissues of the coral Acropora muricata under thermal stress. FEMS Microbiol. Ecol. 2015, 91, fiv142. [CrossRef] [PubMed] 